\title{
Hypopharyngeal Cancer Pathologic Primary Tumor TNM Finding v8
}

National Cancer Institute

\section{Source}

National Cancer Institute. Hypopharyngeal Cancer Pathologic Primary Tumor TNM

Finding v8. NCI Thesaurus. Code C132926.

A pathologic finding about one or more characteristics of hypopharyngeal cancer, following the rules of the TNM AJCC v8 classification system as they pertain to staging of the primary tumor. 